\title{
PELATIHAN PENGEMASAN DAN PEMASARAN PRODUK SECARA DIGITAL
}

\author{
Sukron Makmun \\ Progam Studi Ilmu Administrasi Negara \\ Sekolah Tinggi Ilmu Administrasi Pembangunan Jember \\ *Email: makmunjayaraya@gmail.com
}

\begin{abstract}
ABSTRAK
Pengemasan dan pemasaran produk menjadi salah satu bagian penting dalam sebuah proses bisnis produksi produk khususnya makanan dan minuman. Pengemasan dan pemasaran juga berkaitan dengan tercapainya target penjualan yang telah direncanakan. Kemasan yang baik dapat menimbulkan daya tarik dari calon pembeli untuk kemudian memutuskan untuk membeli atau tidak.

Konsep dan aplikasi pemasaran secara digital dapat mendorong meningkatnya penjualan dari sebuah produk. Karena seiring dengan kemajuan teknologi tren dunia pemasaran semakin bervariasi salah satunya adalah tren pemasaran secara online. Progam pelaksanaan pelatihan pengemasan dan pemasaran produk secara digital ini diberikan kepada masyarakat Desa Sruni, Kecamatan Jenggawah, Kabupaten Jember. Dikhususkan kepada kelompok sasaran yaitu kelompok

Usaha Mikro Kecil Menengah (UMKM) bidang makanan ringan Bakpia Barokah Food Industri yang beralamat di Dusun Krajan, RT 01 RW 02,

Desa Sruni Kecamatan Jenggawah, Kabupaten Jember. Pada progam pelatihan ini memiliki target capaian yaitu memberikan pengetahuan dan keterampilan terkait pengemasan yang unik dan menarik serta peninggkatan pemasaran melalui layanan digital.
\end{abstract} Kata kunci: Pelatihan, Pemasaran Digital, Pengemasan Produk 


\section{Analisis Situasi}

Setiap pelaku usaha tentu menginginkan produknya laku keras di pasaran baik di pasar lokal maupun di pasar global. Namun tidak setiap produk mampu menarik hati konsumen untuk memilih produknya di tengah munculnya ragam pilihan. Tidak jarang konsumen justru memilih produk lain yang masih tergolong baru namun memiliki tampilan yang menarik. Untuk produk makanan misalnya, biasanya konsumen lebih cendrung memilih produk yang dikemas dengan kemasan yang unik dan menarik. Oleh karena itu salah satu faktor yang harus diperhatikan dalam usaha industri makanan adalah kemasan produk yang menarik supaya bisa mendapatkan minat dari para konsumen untuk membeli.

Secara umum kemasan merupakan bagian terluar dari suatu produk baik makanan ataupun bukan yang berfungsi melindungi produk. Menurut Kotler \& Keller (2009:27), pengemasan diartikan sebagai kegiatan merancang dan memproduksi wadah atau bungkus sebagai sebuah produk. Sebetulnya fungsi utama dari kemasan adalah melindungi produk dari cuaca, guncangan, dan benturan-benturan terhadap benda lain. Namun dewasa ini kemasan menjadi salah satu alat bagi pelaku bisnis untuk menarik minat konsumen agar membeli produk yang mereka produksi dan mereka jual. Kemasan yang dibuat sedemikian rupa sehingga tampil menarik dapat menciptakan ekuitas merek dan dapat mendorong naiknya penjualan secara signifikan. Karena kemasan merupakan bagian pertama yang akan dinilai terhadap sebuah produk sehingga calon konsumen memutuskan untuk membeli atau tidak membeli sebuah produk. Oleh karena itu sitiap produsen bisanya akan merancang kemasan sedemikian rupa sehingga dapat meraih perhatian para konsumen untuk membeli produk yang mereka jual. Melalui kemasan biasanya produsen berupaya untuk menciptakan kesan yang baik terhadap barang yang mereka produksi dan mereka jual. Oleh karena itu setiap produsen berupaya untuk menciptakan kemasan baru yang berbeda-beda walaupun 
sebenarnya produk yang mereka jual memiliki kesamaan dengan produk yang dijual oleh produsen yang lain segmenatasi pasar yang sama.

Berdasarkan permasalahan tersebut tim pengabdi tertarik memberikan pelatihan kepada para pelaku Usaha Mikro Kecil dan Menengah (UMKM) bidang makanan kering untuk mulai melakukan pengemasan yang baik dan mulai merambah pada model pamasaran digital. Selain itu tim juga mencoba mencari persoalanpersoalan yang dihadapi oleh para pelaku UMKM di tengah krisis yang disebabkan oleh pandemi Covid-19 ini. Karena seperti yang kita ketahui bersama aktivitas ekonomi masyarakat di masa pandemi ini banyak sekali yang mengalami penurunan tidak terkecuali UMKM. Tidak jarang diantara mereka justru terpaksa harus gulung tikar (bangkrut). Oleh karena itu UMKM perlu kiranya mencari alternatifalternatif pemecahan masalah agar produk mereka mampu bertahan dan tetap menjadi pilihan masyarakat.
Berdasarkan hasil kajian lingkungan di wilayah desa binaan Sekolah Tinggi Ilmu Administrasi Pembangunan Jember tim pengabdian STIA Pembangunan tertarik untuk melaksanakan kegiatan pengabdian masyarakat bekerja sama dengan Nabi'ul Fidyan salah satu pengelola UMKM bidang makanan ringan Bakpia Barokah Food Industri yang beralamat di Dusun Krajan, RT 01 RW 02, Desa Sruni Kecamatan Jenggawah, Kabupaten Jember. Dipilihnya sebagai mitra karena usaha ini telah ada sejak era orde baru pada era tahun 90an. Menariknya pada era itu usaha ini berada pada puncak keemasan. Padahal seperti yang kita ketahui bersama pada era itu khususnya pada tahun 1998 Indonesia sedang dilanda krisis ekonomi. Namun usaha ini justru berada pada masa puncak kejayaan dengan mempekerjakan 50 orang lebih baik itu tenaga laki-laki ataupun perempuan.

Berdasarkan penuturan dari Fidyan selaku pengelola, pada era tahun 90an masih sangat jarang sekali masyarakat Jember yang bergerak dibidang usaha produksi 
makanan ringan. Mereka rata-rata bergerak dibidang pertanian atau menjadi buruh. Masyarakat yang bergerak dibidang makanan ringa kebanyakan masuk pada jalur distribusi baik sebagai distributor maupun agen. Oleh karena itu Fidyan kala itu melihat celah besar yang bisa dia masuki untuk menjadi produsen atau centra makanan ringan. Sejak awal berdiri Fidyan memilih untuk memproduksi Bakpia Kering dan kue kacang. Selain mudah dibuat pelaku usaha tersebut tergolong masih sangat jarang. Jikalaupun ada hanya sebatas pekerjaan sampingan yang tidak digarap secara serius. Oleh karena itu Fidyan kemudian memutuskan untuk melakukan riset dengan memproduksi skala kecil dan dipasarkan dengan cara dititipkan di toko-toko sekitar wilayah Kecamatan Jenggawah. Rupanya respon pasar begitu baik. Dari yang awalnya hanya diproduksi oleh Fidyan bersama istrinya kemudian dibantu oleh para tetangga sekitar baik dalam proses produksi maupun proses distribusi. Kue kering dengan bahan utama berupa tepung terigu itu rupanya sangat diminati masyarakat kala itu. Tidak heran jika dikala itu Fidyan mampu menghabiskan tepung terigu hingga 500 kilogram dalam sehari dengan dibantu sebanyak 50 tenaga kerja.

Namun sayangnya menurut Fidyan usaha yang dia bangun bersama sang istri secara grafik terus mengalami penurunan. Apalagi ditengah pandemi seperti sekarang ini. Sejak masuk era pandemi Covid19 Fidyan hanya mampu menghabiskan 50 kilogram tepung terigu dalam 3 hari dengan dibantu oleh 3 orang karyawan wanita. Sebenarnya penurunan skala produksinya ini bukan semata-mata karena Covid 19. Namun menurutnya justru dikarenakan usaha yang dia dirikan selama ini hanya dikelola secara konvensional. Baik dari sisi pengemasan maupun dari sisi model dan rasa dari produk yang dia produksi. Padahal para pesaing yang bergerak dalam segmen yang sama paham betul akan pentingnya pengemasan dan pemasaran produk melalui layanan digital. Fidyan yang hanya mengandalkan pemasaran secara konvensional mulai 
memahami pentingnya melakukan pemasaran melalui online.

STIA Pembangunan melalui program pengabdian kepada masyarakat hadir untuk membantu memberikan pemahaman dan pelatihan singkat kepada Fidyan untuk meningkatkan penjualan baik secara online maupun offline dengan membenahi proses pengemasan dan menambah jalur pemasaran melalui media online baik itu melalui market place ataupun melalui media sosial. Pengemasan ulang produk dengan model dan desain yang menarik diharapkan mampu meningkatkan penjualan secara signifikan. Pemasaran melalui media online diharapkan produk yang diproduksi oleh Fidyan tidak hanya menjangkau pasar lokal namun juga diharapkan mampu menembus pasar regional hingga pasar nasional.

\section{Landasan Teori}

a. Pengertian Kemasan

Menurut Klimchuk dan Krasovec, (2006:33) kemasan diartikan sebagai sebuah desain kreatif yang mengaitkan bentuk, struktur, material, warna, citra, tipografi dan elemen-elemen desain yang di dalamnya menyertakan informasi produk agar produk dapat dipasarkan. Kemasan ini dipergunakan sebagai media untuk membungkus produk, melindungi produk, mengirim produk, mengeluarkan, menyimpan, serta mengidentifikasi dan membedakan sebuah produk di pasar.

Menurut Kotler \& Keller (2009:27), pengemasan diartikan sebagai kegiatan merancang dan memproduksi wadah atau bungkus sebagai sebuah produk. Sebetulnya fungsi utama dari kemasan adalah melindungi produk dari cuaca, guncangan, dan benturan-benturan terhadap benda lain. Namun dewasa ini kemasan menjadi salah satu alat bagi pelaku bisnis untuk menarik minat konsumen agar membeli produk yang mereka produksi dan mereka jual.

Kemasan apa bila dirancang sedemikian rupa secara baik dan unik bisa membangun ekuitas brand atau merek dan mampu mendorong penjualan suatu produk. Karena kemasan merupakan bagian pertama dari sebuah produk yang dilihat oleh 
calon pembeli atau konsumen yang akan menarik atau menyingkirkan pembeli. Pengemasan suatu produk ini biasanya dilakukan oleh para produsen agar bisa menarik minat konsumen terhadap pembelian barang. Melalui kemasannya produsen berupaya untuk menghadirkan kesan yang baik pada produk yang mereka hasilkan dengan menciptakan model kemasan yang beraneka ragam, unik dan menarik sehingga memiliki kesan yang berbeda dengan produk pesaing pada segmentasi pasar yang sama.

b. Fungsi Kemasan

Tidak hanya perusahaan besar, pelaku UMKM pun kini mulai memperhatikan kemasan dari produk yang mereka hasilkan dan mereka jual. Para pelaku UMKM kini tidak lagi menganggap kemasan hanya sebagai pelindung dari produk saja. Namun kemasan juga mampu menjadi salah satu media promosi dari sebuah produk itu sendiri.

Simamora (2007) dalam tulisannya mengemukakan proses pengemasan suatu produk mempunyai dua fungsi yaitu:

\section{Fungsi Protektif}

Kemasan dapat berfungsi menjadi pelindung bagi sebuah produk. Hal ini berkenaan dengan proteksi sebuah produk dari perbedaan iklim, proses distribusi dan prasarana transportasi, yang semua dapat merusak produk jika dibiarkan tanpa kemasan. Melalui pengemasan protektif, para calon konsumen tidak perlu harus khawatir untuk menanggung risiko pembelian produk yang rusak atau cacat.

\section{Fungsi Promosional}

Peran kemasan kini tidak hanya dibatasi pada perlindungan dari sebuah produk saja. Namun dewasa ini kemasan juga dijadikan sebagai alat atau sarana promosional dari sebuah produk. Menyangkut promosi, perusahaan harus mempertimbangkan preferensi konsumen terkait warna, ukuran, dan penampilan sebuah kemasan produk.

$$
\text { Pengertian Pemasaran Online }
$$

Pemasaran bermula dari kenyataan bahwa manusia adalah makhluk yang memiliki kebutuhan dan keinginan. Kebutuhan dan keinginan itu menciptakan suatu keadaan yang tidak menyenangkan dalam diri 
seseorang yang harus dipecahkan melalui pemilikan produk untuk memuaskan kebutuhan dan keingginan pelanggan1 . Konsep pokok dalam pemasaran adalah bertujuan untuk memberikan kepuasan terhadap keinginan dan kebutuhan konsumen, atau berorientasi pada konsumen2. Konsep konsumen mengajarkan bahwa kegiatan pemasaran suatu perusahaan harus dimulai dengan usaha mengenal dan merumuskan keinginan dan kebutuhan dari konsumen.

Dalam melakukan pemasaran perusahaan harus menyusun dan merumuskan kebijakan-kebijakan seperti kebijakan produk, promosi, harga dan saluran distribusi. Agar kebutuhan dan keinginan konsumen dapat terpenuhi secara maksimal dan memuaskan. Secara definitif dapat dikatakan bahwa konsep pemasaran adalah suatu konsep manajemen dalam bidang pemasaran yang berorientasi pada kebutuhan dan keinginan konsumen dengan dukungan dari kegiatan pemasaran yang terarah yang memberikan kepuasan konsumen sebagai kunci keberhasilan organisasi dalam usahanya mencapai tujuan yang telah ditetapkan dalam perusahaan. Pemasaran adalah suatu proses sosial yang di dalamnya individu dan kelompok mendapatkan apa yang yang mereka butuhkan dan inginkan dengan menciptakan, menawarkan, dan secara bebas mempertukarkan produk yang bernilai dengan pihak lain3 . Dalam konteks bisnis, pemasaran mencakup menciptakan hubungan pertukaran muatan nilai dengan pelanggan yang menguntungkan. Karena itu, pemasaran sering disebut dengan proses yang dilakukan perusahaan dalam menciptakan nilai bagi pelanggan dan membanggun hubungan yang kuat dengan pelanggan, dengan tujuan menangkap nilai dari pelanggan sebagai imbalanya.

Dalam melakukan proses pemasaran suatu perusahaan harus melakukan empat langkah dalam melakukan proses pemasaran diantaranya adalah perusahaan berkerja untuk memahami pelanggan, menciptakan nilai unggul bagi pelanggan, membangun 
hubungan yang kuat dengan pelanggan, dan terakhir perusahaan menuai hasil dari menciptakan nilai unggul bagi pelanggan4 . Jadi pemasaran merupakan interaksi yang berusaha untuk menciptakan hubungan pertukaran. Tetapi pemasaran bukanlah suatu cara yang sederhana yang tidak sekedar untuk menghasilkan penjualan saja, pertukaran hanyalah merupakan satu tahap dalam proses pemasaran. sebenarnya pemasaran itu dilakukan baik sebelum dan sesudah pertukaran. Pemasaran Online dapat diartikan dengan sistem pemasaran interaktif yang menggunakan satu atau lebih melalui media iklan untuk menghasilkan tangggapan, respon dan atau transaksi yang dapat diukur pada suatu lokasi konsumen serta tanpa adanya kontak langsung/tatap muka dengan penjual dan konsumen. Dan pembayaran dilakukan melalui internet atau media sosial yang telah di tetapkan oleh penjual produk tersebut.

2. Manfaat Pemasaran Online Pemasaran Online sanggat banyak manfaatnya baik bagi pelanggan atau konsumen dan bagi para pemasar itu sendiri, di antara manfaat itu adalah7 : 1) Manfaat bagi para pembeli atau pelanggan di antaranya yaitu: a. Kemudahaan. Para pelanggan dapat memesan produk 24 jam di mana pun mereka berada. Pelanggan tidak harus pergi ke tempat para perusahaan berjualan. b. Informasi. Para pelanggan dapat memperoleh setumpuk informasi komparatif tentang perusahaan, produk, dan pesaing tanpa meninggalkan kantor ataupun rumah mereka. c. Rongrongan yang lebih sedikit. Para pelanggan tidak perlu menghadapi atau melayani bujukan dan faktorfaktor emosional, mereka tidak perlu antri dalam melakukan pembelian. $d$. Pembeli dapat memesan barang sesuai dengan keinginan mereka. Pembeli dapat secara langsung mengomunikasikan keinginan mereka kepada perusahaan atas barang/jasa yang mereka butuhkan. Sehingga pembeli dapat mengetahui kelebihan serta kekurangan dari barang tersebut. 2) Manfaat bagi para pemasar: a. Penyusuaian yang cepat terhadap kondisi pasar. Perusahaanperusahaan dapat dengan cepat dengan menambahkan produk pada 
tawaran mereka serta mengubah harga dan deskripsikan produknya.

\section{Pengertian Media Sosial} Secara garis besar media sosial dapat dikatakan sebagai sebagai media online, di mana para penggunanya (user) melalui aplikasi berbasis internet yang penggunanya dapat berbagi, berpartisipasi, dan menciptakan konten berupa blog, wiki, forum, jejaring sosial, dan ruang dunia virtual yang disokong oleh teknologi multimedia yang canggih.8 Internet, media sosial dan teknologi multimedia menjadi satu kesatuan yang sulit dipisahkan serta mendorong pada hal-hal baru. Saat ini medsos yang paling banyak digunakan dan tumbuh pesat berupa jejaring sosial, blog dan wiki. Dalam artikelnya berjudul "Use $r$ of the World, United The Challenges and Opportunities of Social Media," di Majalah Business Horizons (2010) halaman 69-68, Andreas M Kaplan dan Michael Haenlein. membuat klasifikasi untuk berbagai jenis media sosial yang ada berdasarkan ciri-ciri penggunaannya. Menurut mereka, pada dasarnya media sosial dapat dibagi menjadi enam jenis, yaitu:

a. Proyek kolaborasi website, di mana penggunanya diizinkan untuk dapat mengubah, menambah, atau pun membuang konten-konten yang termuat di website tersebut, seperti Wikipedia.

b. Blog dan microblog, di mana user mendapat kebebasan dalam mengungkapkan suatu hal di blog itu, seperti perasaan, pengalaman, pernyataan, sampai kritikan terhadap suatu hal, seperti Twitter.

c. Konten atau isi, di mana para user di website ini saling membagikan konten-konten multimedia, seperti e-book, video, foto, gambar, dan lainlain seperti Youtube.

d. Situs jejaring sosial, di mana user memperoleh izin untuk terkoneksi dengan cara membuat informasi yang bersifat pribadi, kelompok atau sosial sehingga dapat terhubung atau diakses oleh 
orang lain, seperti misalnya Facebook.

e. Virtual game world, di mana pengguna melalui aplikasi 3D dapat muncul dalam wujud avatar-avatar sesuai keinginan dan kemudian berinteraksi dengan orang lain yang mengambil wujud avatar juga layaknya di dunia nyata, seperti online game.

f. Virtual social world, merupakan aplikasi berwujud dunia virtual yang memberi kesempatan pada penggunanya berada dan hidup di dunia virtual untuk berinteraksi dengan yang lain. Virtual social world ini tidak jauh berbeda dengan virtual game world, namun lebih bebas terkait dengan berbagai aspek kehidupan, seperti Second Life.

Adapun ciri-ciri dari media sosial adalah sebagai berikut: a) Konten yang disampaikan dibagikan kepada banyak orang dan tidak terbatas pada satu orang tertentu. b) Isi pesan muncul tanpa melalui suatu perantara orang lain dan tidak ada gerbang penghambat. c) Isi disampaikan secara online dan langsung. d) Konten dapat diterima secara online dalam waktu lebih cepat dan bisa juga tertunda penerimaannya tergantung pada waktu interaksi yang ditentukan sendiri oleh pengguna. e) Media sosial menjadikan penggunanya sebagai kreator dan aktor yang memungkinkan dirinya untuk beraktualisasi diri. f) Dalam konten medsos terdapat sejumlah aspek fungsional seperti identitas, percakapan (interaksi), berbagi (sharing), kehadiran (eksis), hubungan (relasi), reputasi (status) dan kelompok (group). 3. Manfaat, Peran dan Fungsi Media Sosial Melihat perkembangan media sosial yang terus berkembang, pengguna harus mengetahui manfaat, peran dan fungsi dari media sosial. Adapun manfaat, peranan dan fungsi media sosial sebagai berikut: 1) Sarana belajar, mendengarkan, dan menyampaikan. Berbagai aplikasi media sosial dapat dimanfaatkan untuk belajar melalui beragam informasi, data dan isu yang termuat 
di dalamnya. Pada aspek lain, medsos juga menjadi sarana untuk menyampaikan berbagai informasi kepada pihak lain. Konten- konten di dalam media sosial berasal dari berbagai belahan dunia dengan beragam latar belakang budaya, sosial, ekonomi, keyakinan, tradisi dan tendensi. Oleh karena itu, benar jika dalam arti positif, media sosial adalah sebuah ensiklopedi global yang tumbuh dengan cepat. Dalam konteks ini, pengguna media sosial perlu sekali membekali diri dengan kekritisan, pisau analisa yang tajam, perenungan yang mendalam, kebijaksanaan dalam penggunaan dan emosi yang terkontrol. 2) Sarana dokumentasi, administrasi dan integrasi. Bermacam aplikasi medsos pada dasarnya merupakan gudang dan dokumentasi beragam konten, dari yang berupa profil, informasi, reportase kejadian, rekaman peristiwa, sampai pada hasil- hasil riset kajian. Dalam konteks ini, organisasi, lembaga dan perorangan dapat memanfaatkannya dengan cara mem bentuk kebijakan penggunaan media sosial dan pelatihannya bagi segenap karyawan, dalam rangka memaksimalkan fungsi media sosial sesuai dengan target-target yang telah direncanangkan. Beberapa hal yang bisa dilakukan dengan medsos, antara lain membuat blog organisasi, mengintegrasikan ber bagai lini di perusahaan, menyebarkan konten yang relevan sesuai target di masyarakat, atau memanfaatkan media sosial sesuai kepentingan, visi, misi, tujuan, efisiensi dan efektifitas operasional organisasi.

Sarana perencanaan, strategi dan manajemen. Akan diarahkan dan dibawa ke mana media sosial, merupakan domain dari penggunanya. Oleh sebab itu, media sosial di tangan para pakar manajemen dan marketing dapat menjadi senjata yang dahsyat untuk melancarkan perencanaan dan strateginya. Misalnya saja untuk melakukan promosi, menggaet pelanggan setia, menghimpun loyalitas customer, menjajaki market, mendidik publik, sampai menghimpun respons masyarakat. 4). Sarana kontrol, evaluasi dan pengukuran. Media sosial berfaedah untuk melakukan kontrol organisasi dan juga mengevaluasi berbagai 
perencanaan dan strategi yang telah dilakukan. Ingat, respons publik dan pasar menjadi alat ukur, kalibrasi dan parameter untuk evaluasi. Sejauh mana masyarakat memahami suatu isu atau persoalan, bagaimana prosedur-prosedur ditaati atau dilanggar publik, dan seperti apa keinginan dari masyarakat, akan bisa dilihat langsung melalui medsos.

\section{Pergerakan keinginan,} ekspektasi, tendensi, opsi dan posisi pemahaman publik akan dapat terekam dengan baik di dalam media sosial. Oleh sebab itu, media sosial juga dapat digunakan sebagai sarana preventif yang ampuh dalam memblok atau memengaruhi pemahaman publik.

Pengertian Penjualan dan Jenis Penjualan Penjualan merupakan salah satu fungsi pemasaran yang sangat penting dan menentukan bagi perusahaan dalam mencapai tujuan perusahaan, memperoleh laba untuk kelangsungan hidup perusahaan dari hasil produksi produk yang telah dihasilkan oleh perusahaan. Penjualan adalah sustu aktifitas perusahaan yang utama dalam memperoleh pendapatan baik untuk perusahaan besar maupun perusahaan kecil, penjualan merupakan sasaran akhir dari kegiatan pemasaran karena pada bagian ini ada penetapan harga, perjanjian dan serah terima barang ataupun perjanjian car pembayaran yang telah disepakati oleh kedua belah pihak, kegiatan penjualan terdiri dari transaksi barang atau jasa baik secara fisik atau jasa untuk mendapatkan pembayaran dan pelunasan piutang. Secara keuangan tingkat pertumbuhan pendapatan dapat ditentukan dengan mendasarkan pada kemampuan keuangan perusahaan.

Tingkat pertumbuhan yang ditentukan dengan hanya melihat kemampuan keuangan dapat dibedakan menjadi dua, yaitu tingkat pertumbuhan atas kekuatan sendiri dan tingkat pertumbuhan berkesinambungan. Tingkat pertumbuhan atas kekuatan sendiri merupakan tingkat pertumbuhan maksimum yang dapat dicapai perusahaan tanpa membutuhkan dana eksternal atau tingkatpertumbuhan yang hanya dipicu oleh tambahan 
atas laba ditahan.tingkat pertumbuhan berkesinambungan adahlah tingkat pertumbuhan maksimum yang dapat dicapai perusahaan tanpa melakukan pembiayaan modal tetapi dengan memelihara perbandingan antara hutang dengan modal. Swastha dan Handoko (2001), "Pertumbuhan atas penjualan merupakan indikator penting dari penerimaan pasar dari produk dan atau jasa perusahaan tersebut, dimana pendapatan yang dihasilkan dari penjualan akan dapat digunakan untuk mengukur tingkat pertumbuhan penjualan".

Berkaitan dengan pertumbuhan penjualan, perusahaan harus mempunyai strategi yang tepat agar dapat memenangkan pasar dengan menarik konsumen agar selalu memilih produknya. Untuk itu faktor-faktor yang mempengaruhi penjualan harus benar-benar diperhatikan.dengan mengetahui faktor-faktor tersebut perusahaan akan dapat menetapkan kebijaksanaan untuk mengantisipasi kondisi tersebut sehingga perusahaan dapat menjual produk dalam jumlah besar dan volume penjualan akan meningkat pula. Dengan meningkatnya laba perusahaan, maka keuntungan yang diperoleh para investor akan meningkat. Menurut Huston dan Brigham (2006:39) berpendapat bahwa perusahaan dengan penjualan yang relatif stabil dapat lebih aman memperoleh lebih banyak pinjaman dan menangung beban tetap yang lebih tinggi dibandingkan dengan perusahaan dengan penjualannya yang tidak stabil. Penjualan barang dagang pada suatu perusahaandagang biasanya hanya disebut penjualan, dimana jumlah transaksi yang terjadi cukup besar bila dibandingkan jenis transaksi lainnya.

Dalam menjual barang dagangan dapat menerapkan sistem transaksi penjualan diantaranya yaitu: a. Penjualan Tunai Penjualan tunai adalah penjualan yang dilakukan oleh perusahaan, di mana transaksi pembayaran dilakukan secara tunai (cash) pada saat barang tersebut diterima oleh pembeli. b. Penjualan Kredit Penjualan kredit adalah penjualan yang dilakukan oleh perusahaan, di mana transaksi pembayaran dilakukan secara kredit 
atau memiliki tempo pembayaran tertentu sesuai dengan kebijakan yang diberikan oleh perusahaan kepada pembeli tersebut. Jenis-jenis penjualan yang sering dikenal masyarakaat dikelompokan sebagai berikut18: 1) Trade Selling Penjualan dapat terjadi apabila produsen dan pedagang besar mempersilakan pengecer untuk berusaha memperbaiki distributor produk- produk mereka. Hal ini para penyalur dengan kegiatan promosi, persediaan dan produk baru. Jadi titik berat dari trade selling adalah pada penjualan melalui penyaluran kepada distributor ke pembeli akhir. 2) Missionary Selling Penjualan dengan usaha meningkatkan daya dorong pembeli untuk membeli barang-barang dari penyalur perusahaan. 3) Technical Selling Technical Selling berusaha meningkatkan penjualan dengan pemberian saran dan nasehat kepada pembeli akhir dari barang dan jasanya.

Dalam hal ini penjual mengidentifikasikan dan menganalisis masalah-masalah yang dihadapi pembeli. 4) New Business
Selling New Business Selling berusaha membuka transaksi baru dengan merubah calon pembeli menjadi pembeli. 5) Responsive Selling Setiap tenaga penjualan diharapkan dapat memberikan reaksi terhadap permintaan para pembeli. 2 . Kegunaan Penjualan Adapun kegunaan dari penjualan itu menurut pendapat Assauri adalah sebagai berikut19: a. Untuk menentukan kebijakan dalam persoalan penyusunan anggaran (budgeting) yang meliputi anggaran penjualan, anggaran pembelian, anggaran pengerjaan (manufacturing budget) dan lain sebagainya. b. Untuk pengawasan dalam persediaan (inventory control).

Hal ini karena jika persediaan yang ada terlalu kecil, maka akan mempengaruhi kelancaran dari kegiatan produksi. Oleh karena itu, agar supaya persediaan jangan terlalu besar atau kekurangan maka penjualan dapat dipergunakan sebagai pedoman, terutama dalam melayani bagian produksi. Dalam hal ini hendaknya perlu diusahakan penyeimbangan dengan cara mempengaruhi tingkat persediaan. c. 
Untuk membentuk kegiatan perencanaan dan pengawasan produksi. Dengan adanya penjualan maka perusahan dapat mengetahui kemungkinan kegiatan di kemudian hari, sehingga manajer dapat mengusahakan perbaikan dalam penggunaan peralatan produksinya agar efesien.

Di samping itu, dapat pula dihindari penggunaan kerja lembur (overtime) yang lebih besar, yang biasanya memakan biaya yang lebih mahal serta kualitas yang diperoleh tidak sebaik bila dikerjakan dalam jam kerja biasa (regular time). $d$. Untuk memperbaiki semangat kerja para pekerja, karena adanya perencanaan perluasan (ekspansi) perusahaan. e. Merupakan ukuran yang baik untuk mengevaluasi kegiatan salesman dalam melayani penjualan. f. Berguna untuk mengadakan perencanaan perluasan perusahaan. g. Untuk mengurangi atau pengganti produk yang tidak memberikan keuntungan. h. Untuk pengawasan perbelanjaan (financial control). i. Untuk penyusunan kebijaksanaan kepegawaian (personal policies) yang lebih efektif dan efesiensi. 3. Faktor-faktor yang Mempengaruhi Penjualan Faktorfaktor yang mempengaruhi kegiatan penjualan, di antaranya yaitu20: 1) Kondisi dan Kemampuan Pasar Penjual harus menyakinkan konsumen agar mau membeli sehingga tercapai sasaran target yang telah ditentukan oleh perusahaan/penjual. Penjual harus memahami beberapa masalah yang cukup penting di antaranya: a. Harga produk yang ditawarkan $b$. Jenis dan karakter produk yang ditawarkan c. Syarat penjualan seperti pembayaran, pengantaran, garansi dan sebagainya. Masalah-masalah tersebut menjadi pusat perhatian pembeli sebelum melakukan pembelian. Maka dari itu para penjual harus meningkatkan kepercayaan konsumen untuk membeli produk tersebut dan menyakinkan konsumen. 2) Kondisi pasar Pasar sebagai salah satu sasaran kegiatan penjualan. Hal-hal yang harus diperhatikan kondisi pasar di antaranya: a. Jenis pasarnya, apakah pasar konsumen, pasar industri, pasar penjual, dan lainnya. b. Daya beli. c. Frekuensi pembelian. d. Keinginan 
dan Kebutuhan konsumen. e. Kelompok pembeli dan segmen pasar. 3) Modal Para pemasar di perusahaan akan kesulitan menjual produk/barangnya, apabila para calon konsumen tidak mengenal produk yang ditawarkan. Dalam hal ini perusahaan harus memperkenalkan produk tersebut langsung kepada pembeli atau melakukan secara online. Maka modal yang diperlukan seperti alat transportasi, tempat usaha, promosi, pemasaran dan alat modal lainya sebagai penunjang penjualan. Perusahaan harus memiliki modal yang cukup untuk memenuhi kegiatan tersebut. Apabila modal kerja perusahaan sudah mampu memenuhi target penjualan, modal tersebut bisa dianggarkan sebagai berikut: a. Kemampuan untuk membiayai usaha-usaha untuk mencapai target penjualan. b. Kemampuan untuk membeli bahanbahan mentah untuk dapat memenuhi target. 4) Faktor Lain Faktor-faktor lain seperti: periklanan, peragaan sering mempengaruhi penjualan. Namun untuk melaksanakanya, diperlukan sejumlah dana yang tidak sedikit. Bagi perusahaan yang modalnya banyak kegiatan seperti periklanan dilaksanakan secara rutin dapat dilakukan. Tapi bagi perusahaan yang memiliki modal sedikit kegiatan seperti periklanan jarang dilakukan.

\section{Identifikasi dan Perumusan Masalah \\ Dari uraian di atas, maka} yang menjadi rumusan masalah adalah sebagai berikut:

"Bagaimana meningkatkan penjualan produk dengan melakukan pengemasan yang menarik dan melalui mekanisme pemasaran melalui layanan digital ?"

\section{Tujuan Kegiatan}

Kegiatan pengabdian pada masyarakat ini bertujuan untuk:

a. Memberikan pemahaman tentang pemahaman terhadap pentingnya membangun ketertarikan konsumen melalui pengemasan produk yang baik dan menarik

b. Meningkatkan keterampilan atau skill pelaku UMKM dalam 
memasarkan produk melalui layanan digital.

\section{Manfaat Kegiatan}

Adapun manfaat yang dapat diperoleh setelah berlangsungnya kegiatan pelatihan ini adalah:

a. Meningkatkan penjualan dan omset UMKM.

b. Meningkatkan brand atau merek dari produk yang di produksi oleh UMKM melalui pengemasan yang menarik dengan desain yang unik.

\section{Khalayak Sasaran}

Kelompok sasaran saat melakukan sosialisasi tentang "Pelatihan Pengemasan Produk Dan Pemasaran Produk Secara Digital" yakni: Pengelola UMKM Bakpia Barokah Food Industri. Dusun Krajan, RT 01 RW 02, Desa Sruni Kecamatan Jenggawah, Kabupaten Jember.

\section{VII.Metode Kegiatan}

Kegiatan ini diawali dengan survey lapangan terlebih dahulu, permohonan ijin kepada penanggung jawab wilayah, serta mengumpulkan warga setempat untuk pelaksanaan kegiatan sosialisasi.

$$
\begin{array}{rlr}
\text { Media } & \text { : Video tata cara } \\
& \text { pembuatan panahan } \\
\text { Metode } & : \text { Ceramah } & \text { dan } \\
& \text { praktek. } & \\
\text { Waktu } & : \text { Pukul } 13.00 \text { WIB } \\
& \text { s.d selesai. }
\end{array}
$$

\section{VIII.Evaluasi Kegiatan}

Evaluasi kegiatan ini dilakukan setelah pelaksanaan sosialisasi dan hasil pembuatan dan pengemasan produk maupun pemasaran melalui layanan digital apakah sudah sesuai dengan yang diharapkan atau masih belum.

\section{DAFTAR PUSTAKA}

Klimchuk, Marianne dan Sandra A. Krasovec. 2006. Desain Kemasan. Jakarta: Erlangga.

Kotler dan Keller. 2009. Manajemen Pemasaran. Jilid I. Edisi ke 13.

Jakarta: Erlangga.

Kotler, Philip. 1999. Manajemen Pemasaran. Jilid II. Edisi Milenium. Jakarta: Prenhallindo.

Rangkuti, Freddy. 2005. Analisis SWOT: Teknik Membedah Kasus Bisnis. Jakarta: Gramedia. 
Simamora, Bilson. 2007. Panduan

Riset dan Perilaku Konsumen.

Jakarta: Gramedia. 